\title{
Performance Analysis of Investment Portfolio Strategy Using Warren Buffett, Benjamin Graham, and Peter Lynch Method in Indonesia Stock Exchange
}

\author{
Ganda Hengky Wirawan and Erman Sumirat
}

\section{ABSTRACT}

\begin{abstract}
Warren Buffett, Benjamin Graham, and Peter Lynch are three (3) famous investors' gurus in the world that have already proved that they can outperform the market by value investing method. Method that they are using are based on fundamental analysis and they screen the company's stock based on several key financial ratios and criteria that they found important in analyzing the company. In this project, Author conducted research and study to find out the applicability of the screening method made by the gurus in Indonesia Stock Exchange (IDX) using equally weighted method, back testing it in May 2012 until December 2020 periods, and evaluate the performance of each type of portfolios made using Sharpe ratio, Treynor ratio, and Jensen's alpha. The result of this project is all type of these portfolios are having positive risk adjusted returns. Peter Lynch type of portfolio is having the highest annualized return $24.04 \%$ or $613 \%$ cumulative return, while Warren Buffett and Benjamin Graham are having annualized returns $9.42 \%$ (or cumulative return $216.48 \%$ ) and $8.3 \%$ (or cumulative return $198.27 \%$ ) respectively. Moreover, Author found that those three types of portfolios are having beta $(\beta)$ nearly the same with one (1) means that the portfolios are having same risk with its systematic (market) risk.
\end{abstract}

Keywords: Benjamin Graham, Indonesia Stock Exchange, Peter Lynch, Warren Buffett.

\section{INTRODUCTION}

It is a common sense that people invest in stock market in order to gain return on his investment. Investment is the investor's commitment to allocate his money and resources to obtain positive returns in the future [1]. Two investing styles that are widely known are value investing and growth investing. Value investing is related with value stock that has low valuation compared to current market price, while growth investing is related with growth stock that characterized by high valuation market price compared to its book value.

Benjamin Graham, Warren Buffett, and Peter Lynch are famous investors that widely known and already proofed that they can outperform the market. Benjamin Graham with his Graham-Newman Corp performed 20\% return annually (1936 to 1956 period) versus $12 \%$ market return in the same period (Graham, 2006). Warren E. Buffett, who influenced by Graham and Phil Fisher, beating the market by having 18.6\% average annual return during 1976-2017 period (Patel, 2018). Peter Lynch, with his PEG and growth at a reasonable price (GARP) investing style, is successfully managed fund at Fidelity Magellan with annual return of $29 \%$ during 1977 1990 period.

COVID-19 pandemic in Indonesia is also impacted to IDX,

\author{
Submitted : August 07, 2021 \\ Published : August 31, 2021 \\ ISSN: $2507-1076$ \\ DOI: $10.24018 /$ ejbmr.2021.6.4.1040 \\ Ganda Hengky Wirawan* \\ School of Business and Management ITB, \\ Bandung, Indonesia. \\ (e-mail: \\ gandahengky-wirawan@ ${ }^{\circledR}$ sbm-itb.ac.id) \\ Erman Sumirat \\ School of Business and Management ITB, \\ Bandung, Indonesia. \\ (e-mail: erman.sumirat ${ }^{@}$ sbm-itb.ac.id)
}

*Corresponding Author in March 2020, Indonesia Composite Index (JCI) reached the lowest of 3937 which occurred in March $16^{\text {th }} 2020$ as seen on Fig. 1.

Almost all sectors in IDX were responding this pandemic with depressed condition, where index of each sector in IDX were all declining compared to previous condition in February 2020. There is strong correlation between Covid-19 pandemic and negative market returns in IDX during pandemic situation [3]. This low stock price condition is reflecting fear and panic of the market and therefore making the stock price more bargaining. Most of stocks in IDX are having low price-to-book-value or in undervalued condition, even for stocks that categorized big market capitalization.

For investors, this is the situation where they can safely enter the market for their long-term investment in order to obtain higher returns. Authors find that during this situation, either value or growth stocks are have a potential high return in the future. Those three investment criteria are criteria that made them outperform the market by buying what they know, not depend on market price fluctuation, seeing a company business prospect and its projection in the future, and buying at reasonable or attractive price. Those three (3) investor's gurus are valuing business of a company not following the market fluctuation. 


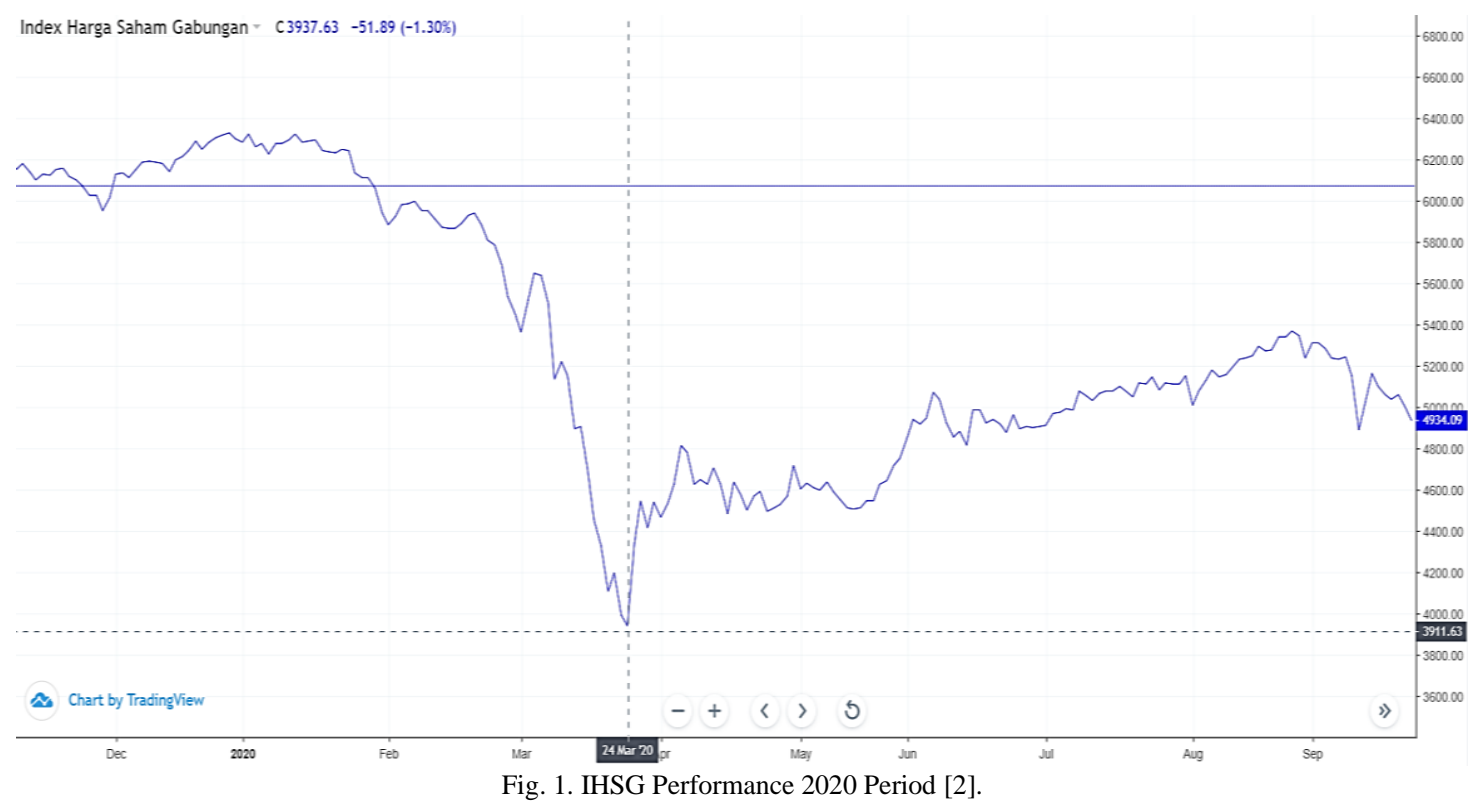

By conducting research on those three portfolios' selection criteria, back testing them in IDX, we can observe and analyze their type of portfolio performance in IDX and choose which stock selection criteria that having optimum return in IDX. Selecting a company with good business, future prospect, and has a healthy financial condition, we will invest with rational thinking. Investor will see market appreciation as a capital gain and market depreciation as an opportunity. Specifically, during this pandemic situation and where almost stocks are in thorough phase, this is the opportunity to find the good companies and invest in IDX.

This research will aim to find out the returns of each gurus' portfolio selection criteria, whether outperform the market or not, and which type of portfolio that has highest return in IDX.

\section{LITERATURE REVIEW}

\section{A. Efficient Market Hypothesis (EMH)}

EMH is introduced by Eugene F. Fama that stating stock market prices is reflecting all information that is available in the market at any point of time [4]. Stock market prices will reach its equilibrium since investors competing one each other to gain profit from the information that is available [5]. According to Eugene F. Fama [4], EMH is consist of three (3) forms: weak form, semi strong form, and strong form. The implication of EMH is that there will be no one will outperform in the market, and it is useless to use technical and fundamental analysis since all information already available in the market.

Contradict with EMH, Benjamin Graham, Warren Buffett, and Peter Lynch are the example of investors that successfully outperform the market. They are evidence for inconsistency of EMH.

\section{B. Risk and Expected Return}

Investors who invest their money in stock market should be aware of their investment risk. Risk is defined as probability of difference on investment return that we will receive with expected return [6]. Damodaran [6] divided risk into firm specific and market risk.
Expected return is defined as the profit or loss of an investment, expressed by (Er) [1].

$$
E(R)=\sum_{i=1}^{n} w_{i} R_{i}
$$

where

$\mathrm{w}_{\mathrm{i}}$ : weight of individual stock in the portfolio;

$\mathrm{R}_{\mathrm{i}}$ : expected rate of return for stock $\mathrm{i}$.

Portfolio standard deviation $(\sigma)$ is a measure of a volatility of a portfolio that measures the price fluctuation from its mean return and expressed by:

$$
\text { Variance }=\sigma^{2}=\sum_{i=1}^{n}\left[R_{i}-E\left(R_{i}\right)^{2}\right] P_{i}
$$

where:

$\mathrm{P}_{\mathrm{i}}$ : probability of the possible rate of return $\mathrm{R}_{\mathrm{i}}$

$$
\sigma=\sqrt{\sum_{i=1}^{n}\left[R_{i}-E\left(R_{i}\right)^{2}\right] P_{i}}
$$

For portfolio that consist of multiple stocks or securities, the standard deviation of a portfolio is calculated using below formula [5]:

$$
\sigma_{\text {port }}=\sqrt{\sum_{i=1}^{n} w_{i}^{2} \sigma_{i}^{2}+\sum_{i=1}^{n} \sum_{j=1}^{n} w_{i} w_{j} \operatorname{Cov}_{i j}}
$$

where:

$\sigma_{\text {port }}:$ standard deviation of the portfolio;

$\mathrm{W}_{\mathrm{i}}$ : weighting of a stock proportion in the portfolio;

$\sigma_{i}^{2}$ : variance rates of return of stock I;

$\mathrm{Cov}_{\mathrm{ij}}$ : covariance between rates of returns for stocks $\mathrm{i}$ and $\mathrm{j}$, where Covij $=r_{i j} \sigma_{i} \sigma_{i} i \neq j$.

\section{Portfolio Return}

Stocks historical price is using adjusted monthly historical closing price derived from yahoofinance.com. Adjusted closing price is used since its price already include all applicable stock's split and dividend paid to investor.

$$
\text { Monthly Portfolio's Return }=\frac{P_{1}-P_{0}}{P_{0}}
$$


where:

$\mathrm{P}_{1}$ : Current monthly price;

$\mathrm{P}_{0}$ : Previous monthly price.

\section{Key Financial Ratio}

In general, financial key ratios are divided into five categories: market, profitability, debt, liquidity and activity ratios [7].

Price to Book Value (P/BV) Ratio:

$$
\begin{aligned}
& B V=\frac{\text { Equity }}{\text { Number of Outstanding Shares }} \\
& P / B V=\frac{\text { Market Price }}{B V}
\end{aligned}
$$

Price to Earnings (P/E) Ratio:

$$
\begin{aligned}
& P / E=\frac{\text { Market } \text { Price }}{E P S} \\
& E P S=\frac{\text { Earnings available to common stockholders }}{\text { number of shares of common stock outstanding }}
\end{aligned}
$$

P/E to Growth Ratio (PEG):

$P E G=\frac{P / E}{g}$

Return on Equity Ratio (ROE):

$R O E=\frac{\text { Earnings available to common stockholders }}{\text { Common stock equity }}$

Debt to Equity Ratio (D/E):

$D / E=\frac{\text { Total Liabilities }}{\text { Common stock equity }}$

\section{Current Ratio:}

Current Ratio $=\frac{\text { Current Assets }}{\text { Current Liabilities }}$

Return on Total Capital (ROTC):

$$
R O T C=\frac{E B I T}{(\text { Total Debt }+ \text { Shareholder Equity })}
$$

\section{E. Portfolio Performance Measurement}

\section{1) Sharpe Ratio}

Known also as reward to volatility ratio [1], it measures excess return of a portfolio compared with risk free investment for each unit of risk and expressed by:

$$
S_{p}=\frac{\bar{R}_{p}-\bar{R}_{f}}{\sigma_{p}}
$$

where:;

$\mathrm{S}_{\mathrm{p}}$ : Sharpe ratio;

$\overline{R_{p}}$ : Average portfolio excess return;

$\overline{R_{f}}$ : Average risk-free return;

$\sigma_{\mathrm{p}}$ : Standard deviation of portfolio.

\section{2) Treynor Ratio}

Treynor ratio is also used to measure portfolio performance by comparing portfolio excess return with its systematic risk $(\beta)$ and expressed by $[1]$ :

$$
T_{p}=\frac{\bar{R}_{p}-\bar{R}_{f}}{\beta_{p}}
$$

where:

$\mathrm{T}_{\mathrm{p}}$ : Treynor ratio;

$\overline{R_{p}}$ : Average portfolio excess return;

$\overline{R_{f}}$ : Average risk-free return;

$\beta_{\mathrm{p}}$ : Systematic risk of portfolio.

To calculate portfolio beta that consist of more than one stock, the calculation is expressed by using following formula:

$$
\beta_{p}=\sum_{i=1}^{n} w_{i} \beta_{i}
$$

where:

$\beta_{\mathrm{p}}$ : Portfolio beta;

$\mathrm{w}_{\mathrm{i}}$ : weight of a stock/asset;

$\beta_{\mathrm{i}}$ : individual stock/asset beta.

\section{3) Jensen Ratio}

Jensen ratio is used to evaluate portfolio by measuring expected return with given portfolio beta and average market return [1] and expressed by:

$$
\alpha_{p}=\bar{R}_{p}-\left[\bar{R}_{f}+\beta_{p}\left(\bar{R}_{m}-\bar{R}_{f}\right)\right.
$$

where:

$\alpha_{\mathrm{p}}$ : Jensen ratio;

$\overline{R_{p}}$ : Average portfolio excess return;

$\overline{R_{f}}$ : Average risk-free return;

$\overline{R_{m}}$ : Average market excess return;

$\beta_{\mathrm{p}}$ : Systematic risk of portfolio.

\section{RESEARCH METHODOLOGY}

Research methodology used in this research is as shown on Fig. 2.

\section{A. Warren Buffett Portfolio Formation}

In forming Warren Buffett type of portfolio, below are the steps:

1. FY 2011 financial statement report is used as basis for first screening and 10 years previous key financial ratio report from financial statement data is used for the other criteria.

2. Since Warren Buffett criteria is using 10 years previous financial statement key ratios data, the company shall be listed in IDX started from Jan 2001 and exist until December 2019.

3. Author also using the judgement to reject stocks that currently has price IDR. 50.

4. Cyclical type company is not being filtered, since Warren Buffett has preference not to invest in cyclical company [8].

5. Screen level of debt by calculating ratio of long-term debt versus net earnings. Stocks chosen shall be less than 5 .

6. Screen stocks that have consistent growth from the last 10 years period (starting from 2002 until 2011). 
7. Screen stocks that have average ROE more than or equal $15 \%$ from last 10 years period.

8. Screen stocks with average ROTC more than or equal $12 \%$ from last 10 years period.

9. Screen stocks that have positive free cash flow value.

10. Screen stocks that have RORE greater than $15 \%$.

11. Avoiding commodity-based type company or cyclical type company [8].

\section{B. Benjamin Graham Portfolio Formation}

In forming Benjamin Graham portfolio, defensive investor [9] stock selection criteria are used as baseline. Not all the criteria are implemented in this research since James B. Rea in his paper stating that implementing all the Benjamin Graham criteria will make things going to be complex [10]. James B. Rea found that only implementing two criteria will outperform the market [10]. Following are the selection criteria used in this research:

1. FY 2011 financial statement report is used as basis for first screening and 10 years previous key financial ratio report from financial statement data is used for the other criteria.

2. Since Benjamin Graham criteria is using 10 years positive earnings history, the company shall be listed in IDX started from Jan 2001 and exist until December 2020.

3. Author also using the judgement to reject stocks that currently has price IDR. 50.

4. Based on 2011 key financial ratio, stocks that have P/BV less than 1.5 are selected.

5. Based on 2011 key financial ratio, stocks that have $\mathrm{P} / \mathrm{E}$ less than 15 are selected.

6. The exception for item 4 and 5 above is using a rule of thumb that $\mathrm{P} / \mathrm{BV}$ times $\mathrm{P} / \mathrm{E}$ should not exceed 22.5. Stocks that matched with these criteria are selected.

7. Stocks that have minimum increase of at least one-third in per share earnings in past ten (10) years using three (3) year averages at the beginning and end are selected.

\section{Peter Lynch Portfolio Formation}

Following screening processes are used in forming Peter Lynch portfolio:

1. FY 2011 financial statement report is used as basis for first screening.

2. Since using three (3) years historical earning growth, from 2009-2011 periods, the stocks shall be listed since 2008 and exist until December 2020.

3. With three (3) years historical earning growth, calculation of the average growth rate is performed and stocks with average growth rate more than $10 \%$ are selected and then selected based on growth percentage categorizations. In his book, Peter Lynch preferred stalwart (10-12\% growth), fast grower (20-25\%), turnaround, cyclical, and asset play type [11]. But in this research author combine with other reference from John P. Reese book where stalwart is for $10-19 \%$ growth and fast grower for the company that has growth rate more than $20 \%$ [12].

4. Based on 2011 financial statement report and three (3) years average earning growth, PEG ratio calculation is performed. Stocks that have PEG less than 1, have a good financial condition, future prospects, and other qualitative aspects are selected. Qualitative and quantitative aspects are also important for Peter Lynch, where he write stock investment is the art, science, and leg work [13].

5. The information of the business and its financial report condition will then be examined and once it has a sign of negative movement of its financial condition and its business prospect, it will sign for selling the stock(s) and conduct portfolio rebalancing [11].

\section{RESUlt AND DisCUSSION}

\section{A. Warren Buffett, Benjamin Graham, and Peter Lynch Portfolio Formation}

Table I is the stocks that passed with Warren Buffett selection criteria. Warren Buffett type of portfolio is concentrated portfolio type, instead of diversified portfolio [8]. In this research, stocks are equally weighted in forming portfolio.

TABLE I: WARREN BUFFETT PORTFOLIO FORMATION

\begin{tabular}{cc}
\hline \hline No. & Stocks \\
\hline 1. & BBRI \\
2. & HMSP \\
3. & KLBF \\
4. & MLBI \\
\hline \hline
\end{tabular}

Table II is showing the stocks that passed with Benjamin Graham selection criteria. In this research, stocks are equally weighted in forming portfolio.

TABLE II: BENJAMIN GRAHAM PORTFOLIO FORMATION

\begin{tabular}{cc}
\hline \hline No. & Stocks \\
\hline 1. & ANTM \\
2. & ARNA \\
3. & ASRM \\
4. & BBNI \\
5. & CTBN \\
6. & GDYR \\
7. & INCO \\
8. & GMTD \\
9. & LION \\
10. & LMSH \\
11. & LTLS \\
12. & PANS \\
13. & SCCO \\
14. & TINS \\
\hline \hline
\end{tabular}

Table III is showing initial stocks formation that passed with Peter Lynch selection criteria. In this research, stocks are equally weighted in forming portfolio.

\begin{tabular}{cccc} 
TABLE III: PETER LYNCH INITIAL PORTFOLIO FORMATION \\
\hline \hline No. & Stocks & $\begin{array}{c}\text { Avg. 3yrs } \\
\text { Growth }\end{array}$ & Category \\
\hline 1. & ACES & $30.46 \%$ & Fast Grower \\
2. & BSDE & $31.54 \%$ & Asset Play \\
3. & CPIN & $154.5 \%$ & Fast Grower \\
4. & EKAD & $126.91 \%$ & Fast Grower \\
5. & EMTK & $-2.77 \%$ & Turnaround \\
6. & KLBF & $30.15 \%$ & Fast Grower \\
7. & ULTJ & $-2.6 \%$ & Turnaround \\
\hline \hline
\end{tabular}

For Peter Lynch portfolio type, if there is any fundamental movement or any changes in business prospect, portfolio rebalancing will be performed [11].

In September 2016, BSDE is sold for portfolio rebalancing since its earning is decreased and the price is getting high 
compared to its earnings. As a replacement candidate for BSDE, TKIM is chosen, refer to Table IV. for Peter Lynch rebalancing-1 portfolio formation.

TABLE IV: PETER LYNCH REBALANCING-1 PORTFOLIO FORMATION

\begin{tabular}{cccc}
\hline \hline No. & Stocks & $\begin{array}{c}\text { Avg. 3yrs } \\
\text { Growth }\end{array}$ & Category \\
\hline 1. & ACES & $30.46 \%$ & Fast Grower \\
2. & TKIM & $-60.99 \%$ & Cyclical and Turnaround \\
3. & CPIN & $154.5 \%$ & Fast Grower \\
4. & EKAD & $126.91 \%$ & Fast Grower \\
5. & EMTK & $-2.77 \%$ & Turnaround \\
6. & KLBF & $30.15 \%$ & Fast Grower \\
7. & ULTJ & $-2.6 \%$ & Turnaround \\
\hline \hline
\end{tabular}

TKIM, categorized as turnaround and cyclical stock (Lynch, 2000), has a depressed condition where P/E reach 66 compared to its industry P/E 8.5, high D/E 1.81 (still in acceptable value since TKIM is expand by build a new pulp and paper plant PT. Oki Pulp \& Paper with 49\% sharing. TKIM was hold until August 2018 since pulp and paper commodity global price is decreasing after its peak on June 2018. And as a replacement for TKIM, ANTM is chosen and kept until end of research period December 2020. Table V. is the stocks formation of Peter Lynch type of portfolio during portfolio rebalancing-2.

TABLE V: PETER LyNCH REBALANCING-2 PORTFOLIO FORMATION

\begin{tabular}{cccc}
\hline \hline No. & Stocks & $\begin{array}{c}\text { Avg. 3yrs } \\
\text { Growth }\end{array}$ & Category \\
\hline 1. & ACES & $30.46 \%$ & Fast Grower \\
2. & ANTM & $79 \%$ & Cyclical \\
3. & CPIN & $154.5 \%$ & Fast Grower \\
4. & EKAD & $126.91 \%$ & Fast Grower \\
5. & EMTK & $-2.77 \%$ & Turnaround \\
6. & KLBF & $30.15 \%$ & Fast Grower \\
7. & ULTJ & $-2.6 \%$ & Turnaround \\
\hline \hline
\end{tabular}

\section{B. Warren Buffett Type Portfolio Returns and Terminal Value}

Fig. 2. is showing the monthly returns of Warren Buffett type portfolio and its comparison with JCI. In overall and long-term view, Warren Buffett type portfolio outperform the market.

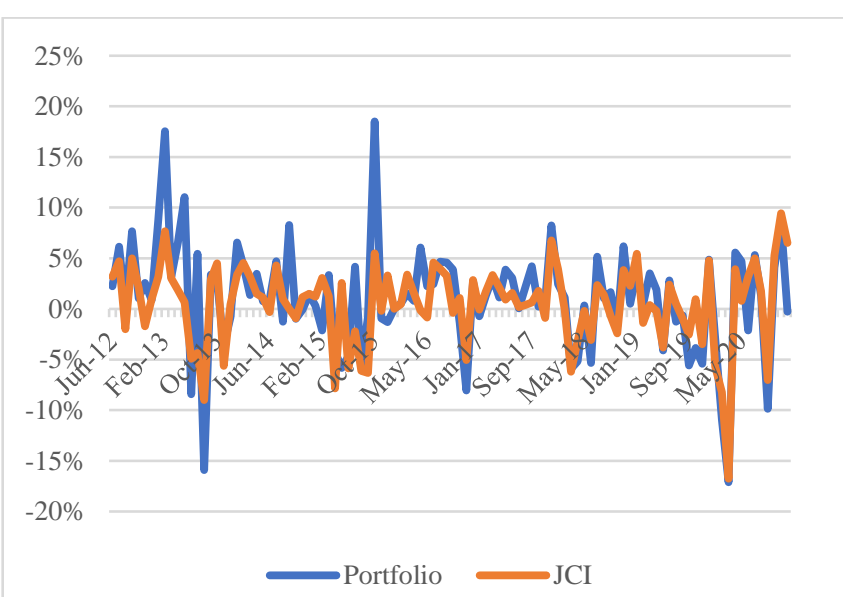

Fig. 2. Comparison of Monthly Returns Warren Buffett Type Portfolio with JCI.
Table VI and VII are showing individual stocks annualized returns, annualized risks (volatility or standard deviation) and portfolio annualized returns, volatility, and terminal value of Warren Buffett portfolio respectively.

TABLE VI: WARREN BUFFETT PORTFOLIO INDIVIDUAL STOCKS ANNUALIZED RETURNS AND RISKS

\begin{tabular}{cccc}
\hline \hline No. & Stocks & $\begin{array}{c}\text { Annualized } \\
\text { Returns }(\%)\end{array}$ & $\begin{array}{c}\text { Annualized Risks } \\
(\%)\end{array}$ \\
\hline 1. & BBRI & 19.72 & 28.4 \\
2. & HMSP & 0.26 & 27.83 \\
3. & KLBF & 9.80 & 23.88 \\
4. & MLBI & 7.88 & 35.82 \\
\hline \hline
\end{tabular}

TABLE VII: WARREN BUFFETT PORTFOLIO ANNUALIZED RETURNS, RISKS, AND TERMINAL VALUE

\begin{tabular}{|c|c|c|c|}
\hline No. & Parameter & $\begin{array}{l}\text { Warren Buffett } \\
\text { Portfolio (\%) }\end{array}$ & JCI $(\%)$ \\
\hline 1. & $\begin{array}{c}\text { Annualized } \\
\text { Returns }\end{array}$ & 9.42 & 5.32 \\
\hline 2. & Annualized Risks & 18.46 & 13.82 \\
\hline 3. & Terminal Value & 216.48 & 156 \\
\hline
\end{tabular}

\section{Benjamin Graham Type Portfolio Returns and Terminal Value}

Monthly returns of Benjamin Graham type of portfolio and its comparison is depicted in Fig. 3. And showing outperformed the market.

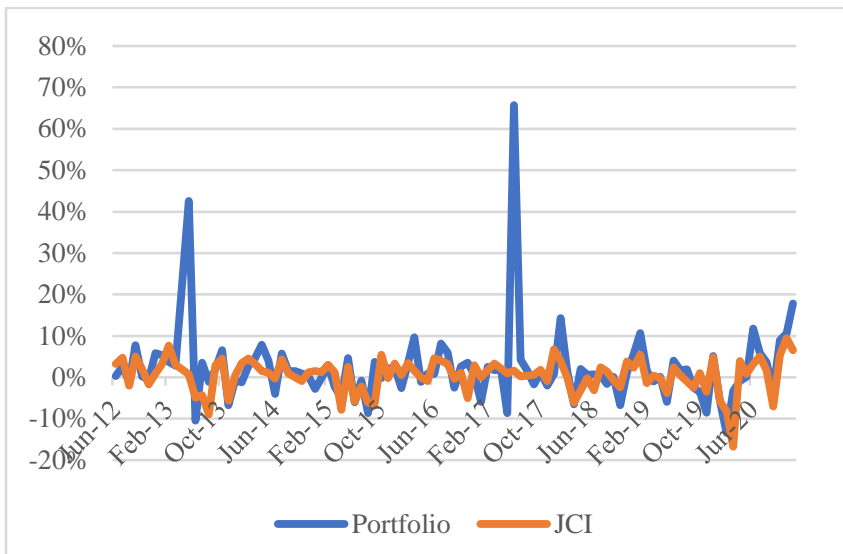

Fig. 3. Comparison of Monthly Returns Benjamin Graham Type Portfolio with JCI.

TABLE VIII: BENJAMIN GRAHAM PORTFOLIO ANNUALIZED RETURNS, RISKS, AND TERMINAL VALUE

\begin{tabular}{cccc}
\hline \multicolumn{4}{c}{ RISKS, AND TERMINAL VALUE } \\
\hline 1. & Parameter & Portfolio (\%) & JCI (\%) \\
2. & Annualized Returns & 8.3 & 5.32 \\
3. & Terminal Valı & 32 & 13.86 \\
\hline \hline
\end{tabular}

Table VIII. and IX. are showing portfolio annualized returns, volatility and terminal value and the individual stocks annualized returns, annualized risks (volatility or standard deviation) of Benjamin Graham portfolio, respectively.

\section{Peter Lynch Type Portfolio Returns and Terminal Value}

Monthly returns of Peter Lynch initial portfolio and its comparison is depicted in Fig. 4. And outperformed the market. 
TABLE IX: BENJAMIN GRAHAM PORTFOLIO INDIVIDUAL STOCKS ANNUALIZED RETURNS AND RISKS

\begin{tabular}{cccc}
\hline \hline No. & Stocks & $\begin{array}{c}\text { Annualized } \\
\text { Returns }(\%)\end{array}$ & $\begin{array}{c}\text { Annualized Risks } \\
(\%)\end{array}$ \\
\hline 1. & ANTM & 10.14 & 55.93 \\
2. & ARNA & 20.13 & 39.58 \\
3. & ASRM & 10.11 & 50.48 \\
4. & BBNI & 19.08 & 71.97 \\
5. & CTBN & -3.82 & 36.88 \\
6. & GDYR & 3.13 & 43.84 \\
7. & INCO & 9.87 & 52.10 \\
8. & GMTD & 32.73 & 372.36 \\
9. & LION & -9.10 & 36.30 \\
10. & LMSH & -5.94 & 75.33 \\
11. & LTLS & 7.13 & 34.38 \\
12. & PANS & 2.67 & 36.73 \\
13. & SCCO & 11.99 & 28.97 \\
14 & TINS & 8.11 & 54.35 \\
15. & JCI & 5.32 & 13.86 \\
\hline \hline
\end{tabular}

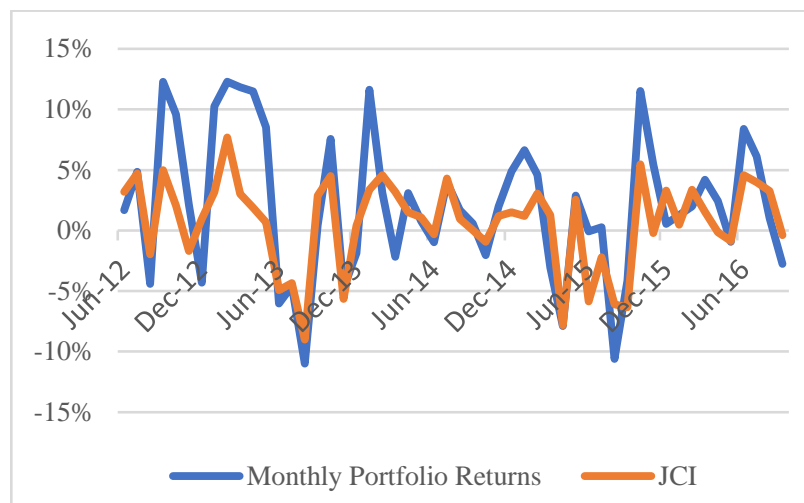

Fig. 4. Comparison of Monthly Returns Peter Lynch Initial Portfolio with JCI.

Table $\mathrm{X}$ and $\mathrm{XI}$ are showing individual stocks annualized returns, annualized risks (volatility or standard deviation) and portfolio annualized returns, volatility, and terminal value of Peter Lynch initial portfolio respectively.

TABLE X: PETER LyNCH INITIAL PORTFOLIO INDIVIDUAL STOCKS

\begin{tabular}{cccc}
\multicolumn{4}{c}{ ANNUALIZED RETURNS AND RISKS } \\
\hline \hline No. & Stocks & $\begin{array}{c}\text { Annualized } \\
\text { Returns }(\%)\end{array}$ & $\begin{array}{c}\text { Annualized Risks } \\
(\%)\end{array}$ \\
\hline 1. & ACES & 15.9 & 15.9 \\
2. & BSDE & 10.1 & 10.1 \\
3. & CPIN & 0.7 & 0.7 \\
4. & EKAD & 11.2 & 11.2 \\
5. & EMTK & 20.3 & 20.3 \\
6. & KLBF & 22.3 & 22.3 \\
7. & ULTJ & 9.8 & 9.8 \\
\hline \hline
\end{tabular}

TABLE XI: PETER LYNCH INITIAL PORTFOLIO ANNUALIZED RETURNS,

\begin{tabular}{cccc}
\multicolumn{4}{c}{ RISKS, AND TERMINAL VALUE } \\
\hline \hline No. & Parameter & Portfolio (\%) & JCI (\%) \\
\hline 1. & Annualized & 12.91 & 8.07 \\
2. & Returns & 20.02 & 12.64 \\
3. & Terminalized Risks & 169.25 & 139.97 \\
\hline \hline
\end{tabular}

Monthly returns of Peter Lynch rebalancing-1 and rebalancing-2 portfolio and their comparison with market is depicted in Fig. 5. And Fig. 6. From those figures it can be seen that both Peter Lynch rebalancing-1 and rebalancing-2 portfolios outperformed the market.

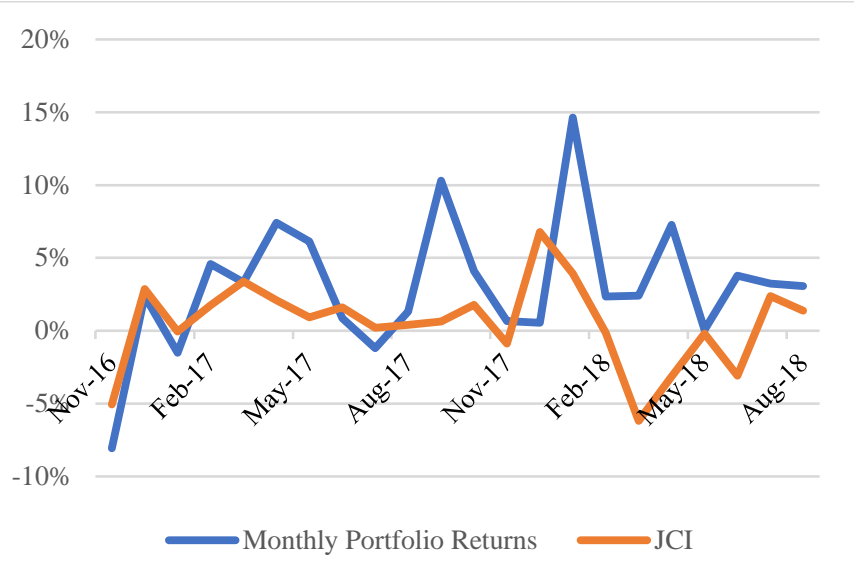

Fig. 5. Comparison of Monthly Returns Peter Lynch Rebalancing-1 Portfolio with JCI.

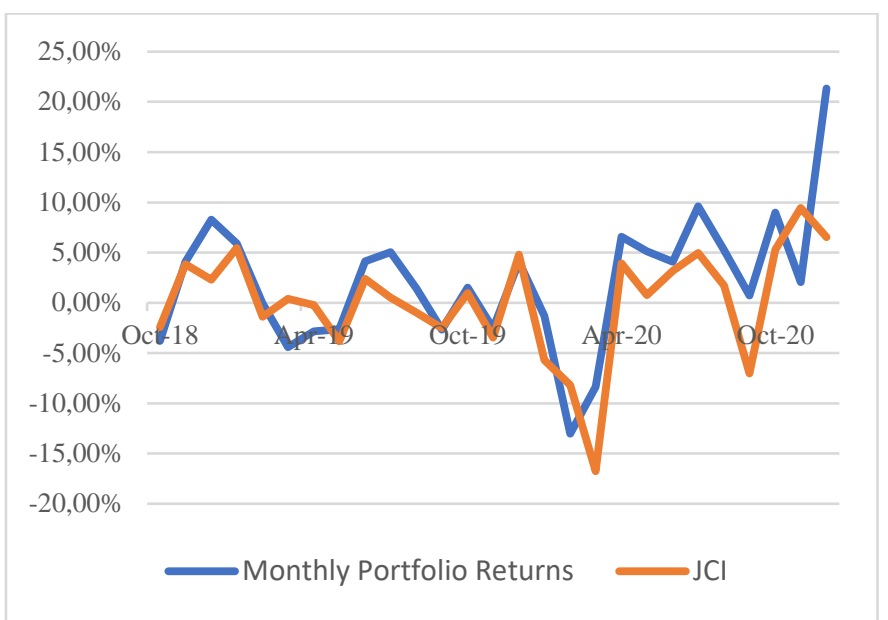

Fig. 6. Comparison of Monthly Returns Peter Lynch Rebalancing-2 Portfolio with JCI.

Table XII, XIII, XIV, XV, are showing individual stocks annualized returns, annualized risks (volatility or standard deviation) and portfolio annualized returns, volatility and terminal value of Peter Lynch rebalancing- 1 and rebalancing2 portfolio, respectively.

TABLE XII: PETER LYNCH REBALANCING-1 PORTFOLIO INDIVIDUAL STOCKS ANNUALIZED RETURNS AND RISKS

\begin{tabular}{cccc}
\multicolumn{4}{c}{ STOCKS ANNUALIZED RETURNS AND RISKS } \\
\hline \hline No. & Stocks & $\begin{array}{c}\text { Annualized } \\
\text { Returns }(\%)\end{array}$ & $\begin{array}{c}\text { Annualized Risks } \\
(\%)\end{array}$ \\
\hline 1. & ACES & 31.3 & 23.5 \\
2. & TKIM & 387.2 & 73.8 \\
3. & CPIN & 17.6 & 32.9 \\
4. & EKAD & 8.5 & 21.0 \\
5. & EMTK & 0.8 & 35.8 \\
6. & KLBF & -11.4 & 20.5 \\
7. & ULTJ & 5.6 & 27.1 \\
\hline \hline
\end{tabular}

TABLE XIII: PETER LYNCH REBALANCING-1 PORTFOLIO ANNUALIZED RETURNS, RISKS, AND TERMINAL VALUE

\begin{tabular}{|c|c|c|c|}
\hline No. & Parameter & Portfolio (\%) & $\mathrm{JCI}(\%)$ \\
\hline 1. & $\begin{array}{c}\text { Annualized } \\
\text { Returns }\end{array}$ & 62.8 & 5.85 \\
\hline 2. & Annualized Risks & 15.31 & 10.17 \\
\hline 3. & Terminal Value & 244.35 & 110.99 \\
\hline
\end{tabular}


TABLE XIV: PETER LyNCH REBALANCING-2 PORTFOLIO INDIVIDUAL STOCKS ANNUALIZED RETURNS AND RISKS

\begin{tabular}{cccc}
\hline \multicolumn{4}{c}{ STOCKS ANNUALIZED RETURNS AND RISKS } \\
\hline No. & Stocks & $\begin{array}{c}\text { Annualized } \\
\text { Returns }(\%)\end{array}$ & $\begin{array}{c}\text { Annualized Risks } \\
(\%)\end{array}$ \\
\hline 1. & ACES & 9.4 & 31.8 \\
2. & ANTM & 45.9 & 75.2 \\
3. & CPIN & 11.8 & 37.9 \\
4. & EKAD & 29.2 & 24.3 \\
5. & EMTK & 22.6 & 59.5 \\
6. & KLBF & 4.7 & 26.0 \\
7. & ULTJ & 9.1 & 25.0 \\
\hline \hline
\end{tabular}

TABLE XV: PETER LYNCH REBALANCING-2 PORTFOLIO ANNUALIZED RETURNS, RISKS, AND TERMINAL VALUE

\begin{tabular}{|c|c|c|c|}
\hline No. & Parameter & Portfolio (\%) & JCI $(\%)$ \\
\hline 1. & $\begin{array}{l}\text { Annualized } \\
\text { Returns }\end{array}$ & 62.8 & 5.85 \\
\hline 2. & Annualized Risks & 15.31 & 10.17 \\
\hline 3. & Terminal Value & 244.35 & 110.99 \\
\hline
\end{tabular}

\section{E. Portfolios Performance Evaluation}

Table XVI and XVII are showing portfolios comparison in terms of annualized return and annualized volatility including its Sharpe, Treynor, and Jensen alpha ratios.

TABLE XVI: PORTFOLIOS ANNUALIZED RETURN AND VOLATILITY COMPARISON

\begin{tabular}{ccc}
\hline \hline Portfolio & $\begin{array}{c}\text { Annualized } \\
\text { Return (\%) }\end{array}$ & $\begin{array}{c}\text { Annualized } \\
\text { Volatility }(\%)\end{array}$ \\
\hline Warren Buffett & 9.42 & 18.46 \\
Benjamin Graham & 8.3 & 32 \\
Peter Lynch Initial & 13.33 & 19.17 \\
Peter Lynch Rebalancing-1 & 62.8 & 5.85 \\
Peter Lynch Rebalancing-2 & 18.96 & 18.94 \\
JCI & 5.32 & 13.86 \\
\hline \hline
\end{tabular}

From Table XVI and XVII it can be concluded that the highest annualized return is Peter Lynch type portfolio. This is also confirmed by its Sharpe ratio, which having the highest value compared to other type of portfolio and JCI. In terms of risk that shall be faced by investor, Peter Lynch Portfolio Rebalancing-1 is having the lowest annualized risk. Both Peter Lynch and Warren Buffett type of portfolio are having lowest volatility risks and have better excess return compared to Benjamin Graham type of Portfolio.

TABLE XVII: PORTFOLIOS BETA, SHARPE, TREYNOR, AND JENSEN ALPHA RATIOS COMPARISON

\begin{tabular}{|c|c|c|c|c|}
\hline Portfolio & $\beta$ & $\begin{array}{c}\text { Sharpe } \\
\text { Ratio }\end{array}$ & Treynor Ratio & Jensen Alpha \\
\hline $\begin{array}{l}\text { Warren } \\
\text { Buffett }\end{array}$ & 1.02 & 0.2 & $3.6 \%$ & $4.11 \%$ \\
\hline $\begin{array}{c}\text { Benjamin } \\
\text { Graham }\end{array}$ & 0.85 & 0.08 & $3.01 \%$ & $2.92 \%$ \\
\hline $\begin{array}{l}\text { Peter Lynch } \\
\text { Initial }\end{array}$ & 1.08 & 0.4 & $7.05 \%$ & $8.05 \%$ \\
\hline $\begin{array}{l}\text { Peter Lynch } \\
\text { Rebalancing- } \\
1 \text { Portfolio }\end{array}$ & 0.5 & 9.75 & $113.26 \%$ & $57 \%$ \\
\hline $\begin{array}{l}\text { Peter Lynch } \\
\text { Rebalancing- } \\
2\end{array}$ & 0.89 & 0.7 & $14.86 \%$ & $18.3 \%$ \\
\hline JCI & - & -0.03 & - & - \\
\hline
\end{tabular}

The best performer portfolio in terms of its Treynor ratio is Peter Lynch type portfolio. It can be seen that Peter Lynch type of portfolio is having beta $(\beta)$ portfolio that nearly same with market (beta $=1$ ) for Peter Lynch Initial Portfolio and going to be lower in Peter Lynch Portfolio Rebalancing-1 and Rebalancing-2, which mean that Peter Lynch type of portfolio can have better excess result with the market risk that relatively the same with JCI benchmark as a basis for beta calculation.

From beta values of each type of portfolios it can be seen that the beta value is less than one (1), means that those three types of portfolios are having low level of systematic risk and less sensitive compared to JCI price movement. Even those beta values are less than one (1) or less risky than market, the risk adjusted return for those three (3) types of portfolios are still outperform the market (JCI).

The best performer from those three (3) types of portfolios according to Jensen's Alpha ratio is Peter Lynch type of portfolio as shown in Table 3.46 which having alpha $8.05 \%$ (Initial Portfolio), 57\% (Rebalancing-1 Portfolio) and 18.3\% (Rebalancing-2 Portfolio). The second performer is Warren Buffett type of portfolio which having alpha $4.11 \%$ and the last performer is Benjamin Graham type of portfolio which having alpha $2.92 \%$. Jensen's alpha will tell us that the positive value is interpreted that the portfolio is outperform the market. All three types of portfolios Jensen's alpha result depicted in Table XVII. are all greater than $0 \%$ which are outperform the market.

\section{CONCLUSION AND RECOMMENDATION}

From the portfolio screening process, formation, back testing its performance from May 2012 until December 2020 period, performance evaluation, and data analysis, it can be concluded that:

1. Peter Lynch type portfolio outperform market and having higher annualized return compared to market (JCI), 24.04 $\%$ versus $5.32 \%$ which give cumulative investment return $613 \%$. This type of portfolio is having positive Treynor ratio and Jensen's alpha, indicating that this type portfolio outperforms the market.

2. Warren Buffett type portfolio outperform the market with annualized return of $9.42 \%$ versus market $5.32 \%$ and give cumulative investment return $216.48 \%$. This type of portfolio is having greater than zero values of Treynor Ratio (3.06 \%) and Jensen's Alpha (4.11\%), indicating that this type of portfolio outperforms the market.

3. Benjamin Graham type portfolio outperform the market with annualized return of $8.3 \%$ versus market $5.32 \%$ and its cumulative investment return is $198.27 \%$. This type of portfolio selection criteria is having greater than zero values of Treynor Ratio (3.01\%) and Jensen's Alpha $(2.92 \%)$, indicating that this type of portfolio outperforms the market.

4. In terms of annualized price volatility, those three types of portfolios are having higher volatility (32\% (Benjamin Graham criteria); $19.17 \%$, 5.85\%, 18.94\% (Peter Lynch Initial, Rebalancing-1 and Rebalancing-2 Portfolio respectively); and $18.46 \%$ (Warren Buffett criteria)) compared to JCI (13.86\%), but they are outperformed JCI. 
5. All of those three (3) types of portfolios are having beta $(\beta)$ that nearly the same as 1 , means that portfolios that created by using either Warren Buffett or Benjamin Graham or Peter Lynch are having lower risk compared to its systematic (market) risk.

6. For long term purposes, more than 3 years period of holding time, it is recommended not to include cyclical stocks in the investment portfolio unless investors just want to invest in shorter time frame following the cyclical cycle.

7. Evaluation of fundamental performance and key financial ratio of a company are playing critical roles when determining keeping the stock or conducting portfolio rebalancing. When there is any sign of reduction on the fundamental performance of the company it is highly recommended to conduct portfolio rebalancing.

\section{REFERENCES}

[1] Bodie, Z. Kane, A., \& Marcus, A. J. (2018). Investments (11 $1^{\text {th }}$ ed.). New York: McGraw-Hill Education.

[2] https://www.tradingview.com/chart/SkgTGuek/.

[3] Herwany, A., Febrian, E., Anwar, M. \& Gunadi, A., (2021). The Influence of the COVID-19 Pandemic on Stock Market Returns in Indonesia Stock Exchange. Journal of Asian Finance, Economics and Business Vol 8(3), 39-47.

[4] Fama, E. F. (1970). Efficient Capital Markets: A Review of Theory and Empirical Work. The Journal of Finance Vol 25(2), 383-417.

[5] Reilly, F. K. \& Brown, K. C. (2012). Investment Analysis \& Portfolio Management $10^{\text {th }}$ ed. South-Western Cengage Learning.

[6] Damodaran, A. (2012). Investment Valuation $3^{\text {rd }}$ ed. John Wiley and Sons, Inc.

[7] Gitman, L. J. \& Zutter, C. J. (2012). Principles of Managerial Finance. $13^{\text {th }}$ ed. Prentice Hall.

[8] Buffett, M. \& Clark, D. (1999). Buffettology. Firtst Fireside Edition. Scribner.

[9] Graham, B. (2006). The Intelligent Investor. Revised ed. Harper Business.

[10] Rea, J. B. (1977). Remembering Benjamin Graham-Teacher and Friend. The Journal of Portfolio Management Summer Vol 3(4). 66-72.

[11] Lynch, P. (2000). One Up on Wallstreet. New York: Simon \& Schuster.

[12] Reese, J. P. \& Forehand, J. M. (2009). The Guru Investor. $1^{\text {st }}$ ed. New Jersey: John Wiley \& Sons, Inc.

[13] Lynch, P. (1994). Beating The Street. Simon and Schuster Paperbacks.

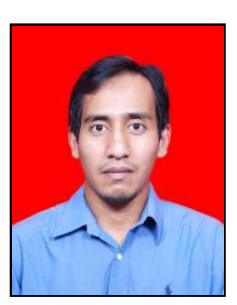

Ganda Hengky Wirawan is a Facility Engineer in PT. Chevron Pacific Indonesia with 15 years' experience in electrical engineering and holds Master Degree on Business Administration from SBM-ITB in 2021 majoring in General Management. His Bachelor Degree was achieved from University of Indonesia in 2006 majoring in Electrical Engineering. His interest is in investing in IDX stock market and widely influenced by Benjamin Graham, Warren Buffett and Peter Lynch style of investment while keep maintaining his core competencies in electrical engineering. He is also being the contributor of MBA SBM ITB Batch-7 Stock Market Investment Community of Practice in the field of fundamental analysis. 